Милан Д. Ђурић

Рачунарски факултет

Универзитет Унион у Београду
UDC: 621.391:004.934]:159.942

DOI: $10.18485 /$ dh.2015.2.ch22

\title{
ДИГИТАЛНИ ИНТЕРАКТИВНИ АНИМИРАНИ ГЕНЕРАТОР ЕМОЦИОНАЛНИХ СТАњА
}

\author{
Сажетак
}

Након детаљног проучавања људских емоција из угла психологије емоција приступио сам решавању проблема интерфејса психологије машине и корисника. У раду се бавим дигитализацијом и дизајнирањем људских емоција, а посебну пажњу усмерио сам на експресије људског лица. Платформа рада је дигитална, а управљачки интерфејс је у потпуности ауторово сопствено остварење. У оквиру платформе, тродимензионални карактери реагују на комбинацију различитих унапред одређених стимулуса. Нагласак је стављен на стимулус у дигиталној платформи, на анимацију стимулуса и на базичну слику у анимираном стимулусу.

У фокусу овог рада налази се дигитални интерактивни анимирани генератор емоционалних стања - Емоционатор. Емоционатор је креиран је у виду флеш анимације, а представља фузију проширених медија и дигиталне уметности. Рад се састоји од следећих делова. У уводним разматрањима наводим опште податке о дигиталној уметности као и контекст у којој је теоријски усидрена моја дигитална платформа. У оквиру дела посвећеног теоријском оквиру рада, описујем теорије емоција у психологији, а затим се осврћем на репрезентацију и симулацију стварности и дизајнирање емоција, а све то повезујем са приказом своје дигиталне платформе Емоционатор. У наредном делу бавим се анимацијом карактера у виртуелном простору у Емоционатору, а затим и самом платформом Емоционатор. Посебан део посвећен је 2Д стимулусима и ЗД анимацији карактера у Емоционатору, док се у последњем делу наводе закључне напомене.

Кључне речи: дигитализација, дигитална уметност, Flash, емоције, дизајнирање емоција, психологија емоција, Емоционатор.

\section{0. Уводна разматрања, дигитална уметност}

Последње деценије XX века дошло је до убрзаног технолошког развоја нарочито у домену компјутера, компјутерски-генерисаних 
медија и појаве дигиталне уметности и генеративне уметности, па се, с правом, овај период може сматрати и својеврсном дигиталном револуцијом. Иако су темељи дигиталне уметности постављени још раних шездесетих година XX века, тек су у последњој деценији XX века софтвер и хардвер постали довољно софистицирани, али и расположиви ширем кругу корисника. Поред тога, појава Интернета пружила је дигиталним уметницима потпуно нове могућности, па су дигитални уметници добили прилику да пасивно коришћење софтверских алата и мултимедијалних програма активирају путем умрежавања и интерактивног повезивања на Интернету. Према литератури, уметници су увек били ти који су у својим уметничким делима и радовима одражавали културу и технологију свог времена, па не изненађује да су управо уметници први експериментисали са дигиталним медијумом деценијама пре него што је проглашена дигитална револуција (Paul, 2008: 7). У прилог томе иде и чињеница да је до краја XX века термин дигитална уметност постао усвојен и распрострањен термин, а у музејима и галеријама широм света почело се са прикупљањем радова дигиталне уметности, као и организовањем изложби дигиталних радова у великој мери.

У оквиру дигиталне уметности посебну пажњу обратио сам на дизајнирање електронске личности које нас представљају у дигиталном свету. Према литератури, ове дигиталне личности или карактери могу да поправе ствари које не волимо на себи и имају потпуну моћ над оним што пројектујемо остатку света (van der Vyver 2012: 15). Да бих боље сагледао своју платформу, погледаћу и контекст у коме се јавља термин „дигитална уметност“.

И сама терминологија која се односи на дигиталну уметност прилично је флуидна и либерална. Најважнији вид дигиталне уметности јесте да она чини креативни чин, креативно функционисање или креативни процес експлицитним, као што то никада није био случај раније у било којој врсти уметности, заправо у целокупној историји уметности (Kuspit 2016). У оптицају су и следећи термини који су у литератури понекада синонимни са дигиталном уметношћу: компјутерска уметност, мултимедијална уметност, нова медијска уметност. Међутим, термин дигитална уметност по- 
крива шири распон уметничких радова и пракси које не описују један обједињени скуп естетике, већ једну широку лепезу радова који се могу подвести под појам дигиталне уметности (Paul 2008: 7).

Теоретичар уметности, Мишко Шуваковић, одређује дигиталну уметност као уметничку праксу остварену дигиталном, у највећој мери компјутерском обрадом података различитог порекла и врсте (Šuvaković 2005: 144). На даље, Шуваковић напомиње да се појам „дигитална уметност“ у литератури понекада синонимно користи као „компјутерска уметност“, међутим, он истиче посебно моменат специфичности дигиталне обраде података у односу на аналогну, тј. механичку. Поред тога, овај аутор констатује да је дигитална обрада слике и звука заправо поступак генерисања нове слике (или звука), или пак трансформација постојећих слика (или звукова) путем дигиталног рачунара. Овде се уводи и појам „дигиталне културе“, који је битан за овај рад, па ћу га погледати за тренутак.

Према литератури, дигитална култура се одређује као масовна медијска култура краја XX и почетка XXI века заснована на друштвеној производњи, размени, рецепцији и потрошњи посредованој дигиталним рачунаром или мрежама дигиталних рачунара (Šuvaković 2005: 144). Иако извесни аутори сматрају да је дигитална уметност ефемерна и нестабилна, очигледно је да њој предстоји још већи развој и напредак. Наиме, експанзија дигиталних технологија, која је започела деведесетих година XX века, наставила се. Следствено томе, дигиталне технологије ће тек остварити свој велики утицај на наше животе и културе, а самим тим, вероватно ће подстицати стварање још више уметничких дела из дигиталног домена.

У овом контексту, а имајући у виду моје остварење, Емоционатор, битним састојком уводих разматрања обухватам и феномен киборга. Ауторка Дона Харавеј (енг. Donna Haraway), с правом, констатује да су крајем двадесетог века сви химере, теоризовани и фабриковани хибриди машине и организма. Укратко, ми смо киборзи (Haraway 2003: 516). Према Харавејовој, киборг је наша онтологија; обезбеђује нам нашу политику. Киборг је кондензована слика како имагинације, тако и материјалне реалности, два здружена центра која структуришу сваку могућност историјске трансформације. У наставку овог дела рада погледаћемо како се објашњава дигитални медијум. 
Пошто дигитални медијум који се користи за стварање дигиталне уметности постоје одређене теме које су специфичне за дигитални медијум. Оно што је специфично за дигитални медијум представљено је следећим концептима, а то су: вештачка интелигенција, телеприсутност и телероботика. Наравно, постоје и још многи други (нпр. естетика базе података, мапирање и визуализација података, између осталог), али ми смо узели у обзир ова три наведена. Телеприсутност (енг. telepresence) дефинише се као способност да се помоћу технолошких средстава буде присутно на удаљеној локацији, на пример, у чет соби на Интернету, док се телероботика (енг. telerobotics) дефинише као руковање локалним роботским уређајем од стране корисника на удаљеној локацији путем Интернета (Paul 2008: 247).

Према литератури, дигитална уметност обухвата: компјутерску уметност, кибернетичку уметност, сајбер уметност, уметност виртуелне реалности, уметност компјутерске мултимедије. Поред тога, обухвата и дигитализацију традиционалних уметности, односно, прецизније: дигиталну фотографију, дигитални филм, дигитални дизајн звука, дигиталну музику, дигитални театар и дигиталну оперу (Šuvaković 2005: 144).

Као што смо видели, на основу прегледане репрезентативне литературе, овако широко одређење дигиталне уметности помаже нам, између осталог, да одредимо полазну тачку за наш дигитални интерактивни анимирани генератор емоционалних стања. Но, пре него што кренемо у детаљнију анализу, у наредном делу, погледаћемо и теоријски оквир који смо користили као платформу за свој рад.

\section{0. Теоријски оквир}

\section{1. Теорије емоција у психологији}

У овом делу рада дајем обједињено дескриптивно тумачење емоција које је послужило као теоријска основа за дигитални интерактивни анимирани генератор емоционалних стања. У оквиру пси- 
хоанализе, не прави се битна разлика између афекта и емоције (види: Krstić 1988). Према овом аутору, афекат и емоција често се јављају у психоаналитичкој литератури, па самим тим, имају битну улогу како у теоријском промишљању, тако и у практичном деловању. Емоције су квантум енергије придодат одређеним идејама.

На даље, емоције се сматрају важним за биолошки опстанак, а помињу се и теорије које истичу развој емоција који је условљен еволуционистичким принципима. Друге дименизије емоција имају биполарну скалу, која имплицира дихотомијску класификацију корисних и штетних последица. Релевантан је концепт емоционалне нестабилности, која се може схватити као тежња ка брзој и недовољно образложеној промени емоционалног стања. Емоционална нестабилност се објашњава у вези са психолошким факторима. Такође, битно је истаћи повезаност са физиолошким стањима организма.

У еклектичком моделу, као што је мој, потребно је погледати разноврсне приступе емоцијама. Објавивши књигу о испољавању емоција код човека и животиња, Дарвин је утицао на развој зоопсихологије, чиме је напустио пут дотадашње психологије свести и отворио простор за један нови методолошки приступ - компаративну психолошку методу. Поред истраживања емоција код животиња, Дарвин је дакле, усмерио своју пажњу и на податке добијене од антрополога који су истраживали различита племена широм света. Увео је три равни емоција: 1. емоције исказане ставом тела, 2. емоције исказане фацијалном експресијом и 3. емоције исказане физиолошким (неуралним) процесима. У вези са емоционалним изразима, Дарвин тврди да су они настали еволуцијом на основу три принципа: 1. принципа корисно асоцираних навика, 2. принципа антитезе, 3. принцип акција које су последица конституције нервног система, а независне од воље и навика.

Као што се из наведеног види, Дарвинов опис испољавања емоција може се шире схватити у оквиру његове теорије еволуције животињскихврста и теорије адаптације. Према његовим схватањима, емотивни изрази су преношени наслеђем и током филогенезе, али су се изменили и одвојили од примарно корисне улоге коју су имали. За саму уметност, па самим тим, и дигиталну уметност, посебно је реле- 
вантан феноменолошки приступ емоцијама о коме сам се информисао из репрезентативне литературе (Ognjenović i Škorc 2005: 305-324), а о коме ће бити речи у предстојећем делу рада.

Феноменолошки приступ емоцијама пратио је историју филозофије вековима, међутим, слободно се може рећи да је немачки филозоф Едмунд Хусерл покретач и главни представник феноменолошке филозофије, као и да је први понудио психолозима феноменолошки метод. Код Хусерла, емоције су интенционалне појаве. Оне су увек усмерене ка нечему, на пример, ка неком објекту, а ове појаве су диктиране из дубљих, есенцијалних слојева личности. Сходно томе, настале су неке теорије чији је заједнички општи став феноменолошки у вези са методолошким приступом проблему. Погледаћемо како се емоције третирају код Сартра.

У складу са својом филозофијом егзистенцијализма, Жан-Пол Сарт (фр. Jean-Paul Sartre) креира теорију емоција. Међутим, његова теорија није у потпуности феноменолошка, већ и когнитивистичког усмерења. Сартр каже да у емотивној свести акценат није на стању унутрашњости, већ на догађају у спољашњости. Другим речима, емоције повезују субјекат и објекат у јединствени догађај, барем по Сартру. Когниција, односно перцепција са расуђивањем, битан су почетак за настанак емоција. Смисао емоција је у трансформацији света око нас. Акција која следи из емоција је иманентни део емотивног склопа трансформације света.

Хилманова теорија емоција настала је шездесетих година XX века када се феноменолошки приступ увелико афирмисао у појединим гранама психологије. Основу теорије сачињавају Хилманови експерименти са сликама људи у емоцијама. Иако следбеник Јунга, Хилман није оптеретио теорију емоција Јунговим схватањима. Говорећи о емоцијама, Хилман се држи Аристотелове шеме и говори о четири узрока, или прецизније то су: 1. делотворни узрок, 2. материјални узрок, 3. формални узрок и 4. финални узрок. Према Хилману, грађа за емоције је енергија, материјал емоција сачињавају: хаос, неред и расуло. Грађа емоција може бити и догађај у телу, грађа је и репрезентација, односно, њена представа у нашој свести. Такође, ту је и инерција исказана кроз мишићну тензију, а емоције су заправо преплитање сила, оних унутрашњих, али и спољашњих. 
Ранија истраживања емоција била су усмерена ка опису снимања гримаса и израза лица. Делови лица, наиме, прате когнитивна збивања и исказују став личности према тим когнитивним збивањима. На пример, широко отворене очи и подигнуте обрве значе пажњу, јако подигнуте обрве - изненађење, стиснуте усне одбијање, итд.

У оквиру Томкинсконове теорије емоције кључни термин јесте aфрекат, а емоције Томкинс схвата као субјективни доживљај. Он наглашава да је афективни систем примаран, а нагонски систем - секундаран, па је зато отворенији према изменама, нпр. учењу. Веома је битно је да међу њима постоји веза која има три компоненте: 1. неуролошка веза (тј. густина неуралног пражњења), 2. бихејвиорална веза (исказује се кроз фацијалне, телесне и висцералне промене), 3. феноменолошка веза (у њој се исказује афекат као мотив). Оно што је битно за моју интерактивну дигиталну платформу јесте главна идеја коју налазим код Томкинса, а то је изражавање емоција (афеката) кроз фацијалну експресију. Импулси са лица одређују свесну компоненту емоција.

Изардова теорија емоција подржава већи део Томкинсових идеја, међутим, Изард их допуњава и развија. Изард сматра да личност сачињавају пет међусобно повезаних подсистема. Пошто су емоције један од тих подсистема, да бисмо их разумели, морамо да познајемо и односе тих подсистема. Афективни систем је примарни мотивациони, когнитивни је примарни комуникациони, а моторни је примарни акциони систем. Емоције, или прецизније афекти, којих по Изарду има девет примарних, садрже три компоненте: 1. електрохемијску или нервну активност, 2. еференту или фацијалну активност и 3. субјективно искуство. Настанак емоција обично захтева активност сва три нивоа, мада Изард посебно наглашава значај фацијалне експресије. Погледаћемо извесне основне идеје Плучика, као и Плучикову теорију емоција.

Веома битна за мој рад јесте Плучикова теорија емоција, па ћу стога погледати неке аспекте Плучикове теорије емоција. Роберт Плучик (енг. Robert Plutchik) је феноменолошким приступом објединио анализу језика којом се описују емоције и њихов биолошки циљ. по- 
ред тога, Плучик примењује опште принципе мерења и примењује их на мерење емоција (Plutchik 1989: 1). Плучик сматра да емоције имају три димензије: интензитет, симиларитет и поларитет (Ognjenović i Škorc 2005: 321).

Према Плучику, интензитет је јачина којом се изражава и доживљава нека емоција. Симиларитет је дименизија сличности и/ или разликовања међу емоцијама, а поларитет - особина да свака емоција има своју супротност. Ове димензије граде тродимензионални простор, у који се може сместити осам емоција. Основне емоције могу се слагати у дијаде или чак и још сложеније склопове, што би било аналогно мешању боја. Па тако, на пример, љубав се тумачи тако што настаје спајањем радости и прихватања. Битно је истаћи да, према Плучику, поред свакодневног, обичног језика, који користимо приликом описивања својих емоција, а који је заправо субјективан, постоје још два језика, барем кад су у питању емоције. Према Плучику то су дескриптивни и функционални језик. Дескриптивни језик служи за описивање опсервација понашања у емоцијама, док функционални језик служи за да се њиме говори о биолошкој усмерености, као и о намени емоција. Плучик сматра да је функционални језик најзначајнији (Ognjenović i Škorc 2005: 323), зато што открива адаптивну природу емоције. У вези са тим, Плучик у осам основних емоција препознаје усмерење организма ка: заштитити, разарању, репродукцији, депривацији, прихватању, одбијању, истраживању и оријентисању. На даље, ови адаптивни циљеви се јављају као четири опозитна пара: 1. заштита-разарање, 2. репродукција-депривација, 3. прихватање-одбијање и 4. истраживање-оријентисање.

Такође, према Плучику, у основи свих емоција налазе се адаптивни процеси. Емотивни субјективни доживљај може, али не мора обавезно, да учествује у томе. Опште је познато да постоје емоције које не дају никакве ефекте на плану субјективног доживљавања. Треба додати још да субјективни доживљаји емоција и дескриптивни, тј. бихејвиорални језик, омогућавају увид у организацију емоција код људи, али и код појединаца. У том смислу, Плучик је развио психометријске технике којима се емотивни живот може снимити и приказати. Поред тога, он сматра да субјективне процене омогућавају 
и поређење интензитета појединих емоција. Не треба сметнути са ума, као што то истиче Плучик, да из сложених емоција настају и црте личности. Суштина је у трајању и једних и других. Иако емоције не трају дуго, уколико их индивидуа учестало користи у одређеном сложају, настаје - црта личности. У раду сам покушао да интегришем неке од управо приказаних аспеката Плучикове теорије емоција.

Поред усвојеног теоријског оквира, преузетог из репрезентативне литературе из психологије емоција, погледаћемо и могућности репрезентације стварности и дизајнирање емоција.

\section{2. Репрезентација и симулација стварности, дизајнирање емоција}

Према литератури, Жан Бодријар се наводи као кључни коментатор постмодерног стања, а посебно се истиче релевантност његове теорије симулације у овом контексту (Toffoletti 2011: 39). Тофолети сматра да нас Бодријар тера да преиспитујемо прихваћене начине схватања слика, а у том самом процесу поставља нова питања о опсегу у оквиру кога можемо да говоримо о репрезентацији и стварности као непроблематичним терминима (Toffoletti 2011: 39).

У својој студији, Манович наглашава да су почетком деведесетих година XX века најпознатији глобални брендови биле компаније које су пословале у домену производње материјала или робе, или обраде физичке материје. Међутим, данас данас се у врху најпрепознатљивијих глобалних брендова налазе имена попут Гугла (енг. Google), Фејсбука (енг. Facebook) и Mајкрософрта (Microsoft) (Manovich 2013: 6). Управо због промене парадигме у овом смеру, потребно је позабавити се психологијом машина и психологијом корисника. Пошто се психологија машина развијала упоредо са вештачком интелигенцијом, вероватно да је повукла за собом неке битне импликације. Приликом стварања првих компјутера, јавиле су се и филозофске, етичке, и друге расправе о психологији машина.

У вези са психологијом корисника, занимљиво је обратити пажњу на потрошачку културу нарочито релевантну у доба

глобализације. У том смислу, јавља се посебна психологија корисника 
машине, тј. компјутера. Овај интерфејс „корисник (тј. човек) - машина (тј. компјутер)“ посебно је релевантан за моју дигиталну интерактивну анимирану платформу управо зато што покушава да разреши одређене недоумице које би се могле јавити током креирања и реализације платформе.

Поред наведеног, поставља се питање дозирање емоција. Да ли се емоције могу, условно речено, дозирати? Да ли се то може радити двосмерно? И у смеру човек-машина (компјутер), али и обрнуто машина (компјутер)-човек? Како се ово дозирање може поспешити и побољшати? Ово су само нека од питања која се могу поставити. Поред тога, у контексту интеракције дигиталне уметности и психологије емоција, могу се поставити и додатна питања: 1. Да ли се емоције могу дизајнирати? 2. Колико компјутер може/не може да дизајнира људске емоције? 3. У којој мери компјутер може да подражава/симулира људске емоције? Управо бих застао код овог последње наведеног питања и погледао бих улогу симулације у овом интерактивном пројекту.

За моју дигиталну платформу битна је и симулација. Као што je, по Жану Бодријару (фр. Jean Baudrillard), двојник несумњиво најстарија од свих протеза које прате историју тела (Bodrijar 1991: 99), и тродимензионални карактери у оквиру мог рада могу се посматрати као нека врста протезе, мада не и клонови корисника и/или учесника. Самим тим, и између корисника-учесника и ове „протезе“ јавља се некакав однос, чак и емоционални. Да ли се онда ове емоције могу дизајнирати, и како? Један од могућих одговора јесте: симулацијом и/или хиперреалношћу. Наравно, упоредо са променама закона вредности, изменила су се три поретка симулакра (Baudrillard 2001: 69), међутим, за моју платформу сматрам најзначајнију последњу, а то је симулација, која представља образац данашњег степена којим управља код (упореди: Baudrillard 2001: 69). У првом и другом степену симулације, реално још постоји, а успешност симулације меримо у односу на стварно. Међутим, код трећег степена симулације, Бодријар сматра да модел сада генерише хиперреалност, тојест свет без правог порекла (види: Lane 2000: 86).

Бодријар каже да смо укинули стварни свет, а потом се пита који то свет још постоји. Да ли је то свет знакова. Међутим, он даје нега- 
тиван одговор. Каже да смо са стварним светом истовремено избрисали свет знакова, а убиство знака јесте оно што крчи пут интегралној стварности (Baudrillard 2006: 59). Говорећи о убиству знака, Бодријар констатује да је оно што је стварно заправо изврнуто хегемонији знака, слика, симулакрум. Другим речима, стварност је подчињена творевини, а ову анализу подржава појам друштва спектакла (упореди: Baudrillard 2006: 59).

У контексту дизајнирања емоција релевантне су и фацијалне експресије чије теоријске поставке никако нису могле да буду пренебрегнуте у мом раду. Постоје многе студије о аутоматском препознавању фацијалне експресије, чије су теоријске поставке узете у обзир, а свакако постоје и различите комерцијалне примене које су доступне, а које служе за препознавање фацијалне експресије. Ипак, у литератури се износи мишљење да ове студије, али и њихове практичне примене јесу далеко од једног прецизног модела (Maiocchi 2015: 94).

Пошто људско тело и људско окружење еволуирају у нове домене и потпуно нове могућности, ове промене имплицирају да се вероватно мењају и наше физичке потребе. Пред нама се налази један читав свет који би требало да искусимо, а то је дигитални свет Интернета (van der Vyver 2012: 73). Према овој ауторки, у овом дигиталном свету ми се отелотворујемо као физички непостојеће људске репрезентације, које се могу назвати електронским личностима. Ван дер Виверова луцидно каже да бити онлајн значи навући друго тело. Управо се овде експериментише идејом онлајн личности који је пажљиво сачињен дигитални прибор верзији из стварног света. У Бодријаровом контексту, ово би била симулација стварности. У овој симулацији, можете бити оно што желите да будете, и створити себе као некога са божанским моћима (van der Vyver 2012: 73).

Дигитални свет дизајнираних емоција може се протумачити као начин превазилажења ограничења физичког света начин превазилажења краја, начин ослобађања од концепта времена. Дигитални интерактивни анимирани карактери у мом дигиталном свету потпуно се уклапају у овако усидрене теоријске поставке. Попут Бодријаровог примера спикера у студију (упореди: Baudrillard 2001: 
230), и моји дигитални карактери прелазе у стварно време догађаја или у надживот у стварном времену, али у истој нестварности.

\section{0. Анимација карактера и виртуелни простор у Емоционатору}

Платформа Емоционатор реализована је дигиталном технологијом, а презентована путем дигиталних медија, у виду поставке дводимензионалне анимације. Спајањем дводимензионалне компјутерске анимације, ЗД анимације и психологије емоција моја платформа добија интердисциплинарни карактер. Поред тога, Емоционатор има и једну додатну димензију. Прецизније, поред доминантне психологије емоција релевантни састојци су и виртуелни простор на самом монитору и у самом компјутеру, као и реални простор, ван компјутера, у коме се налази корисник у мом раду. Дакле, корисника и виртуелни/компјутерски простор повезује психологија емоција. То бих приказао уз помоћ следеће илустрације:

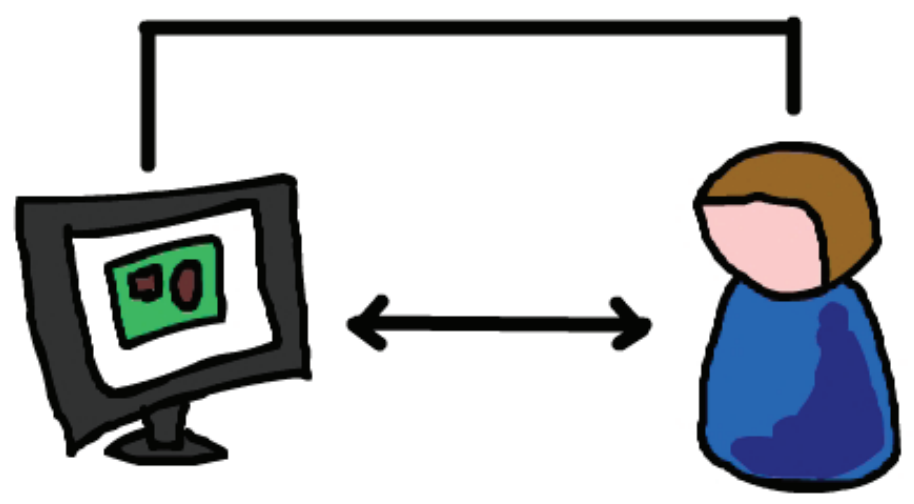

Слика 2.0.1. Виртуелни компјутерски простор - интерфејс „психологија емоција - корисник“ ${ }^{1}$.

Емоционатор је дигитална платформа коју сачињава прозор на коме се налазе виртуелни тродимензионални карактер и анимирани

Илустрација: Милан Ђурић (c) 2010. 
стимулус. Дакле, у мом раду виртуелни карактери налазе се наспрам реалних лица, односно корисника.

Анимације на екранима нису повезане синхорно, већ корисник врши селекцију тродимензионалног карактера према свом избору, као и врсту стимулуса који утице на карактер. Техничко извођење рада подразумевало је паралелну монтажу појединачних секвенци анимације за сва четири карактера. Свака анимација за сваки екран, тј. прозор посебно је изрендерована. Рад подразумева дводименизионалну анимацију и дигиталну платформу.

Платформу рада Емоционатор сачињавају следећи сегменти. Први сегмент је дводимензионална анимација стимулуса и анимација тродимензионалних карактера. У неку руку може се рећи да су ови карактери примарни у односу на стимулусе који су секундарни. Овај сегмент обухвата визуелни и звучни аспект рада. Други сегмент обухвата техничке елементе, у које спадају следеће компоненте: монитор компјутера, тастатура и миш. Ови елементи су посредници између корисника и интерактивне платформе. Уколико Емоционатор сагледавамо концептуално, опрема се не може сматрати самим делом амбијента. Међутим, монитор на коме се одиграва дводимензионална платформа може да се сматра метафором виртуелног компјутерског простора у коме се одиграва симулација, и то симулација емоција.

Основу моје дигиталне платформе у концептуалном и техничком смислу представља анимација тродимензионалних карактера, као и анимација 2Д стимулуса који утичу на те тродимензионалне карактере. Моја платформа реализована је као анимација дводимензионалног стимулуса и анимација тродимензионалних карактера који реагују на те стимулусе. У платформи постоји укупно четири тродимензионална лика на које делују одређени стимулуси. Сваки од ових ликова може да представља један карактер, један психички склоп и дато емотивно стање. Карактери подражавају емоције и емоционалне доживљаје на начин који је то регистровано у литератури. Ови карактери су, условно речено, симулације у Бодријаровом смислу (упореди: Bodrijar 1991).

Путем анимације карактера покушао сам да концептуално анализирам природу ових виртуелних бића, њихово понашање 
и реаговање у виртуелном компјутерском простору. Мислим да се на овај начин може анализирати и испитати и њихов виртуелни идентитет. Поред тога што је њихов идентитет симулација, дакле, подражавање, симулирање емоционалних реакција на стимулусе, односно, надражаје из спољашњег (опет виртуелног) света, они као да имају и свој особени живот и свој особени виртуелни идентитет у контексту у коме се генеришу.

Анимирани стимулус одређује и дефинише понашање и тему саме анимације. Акценат је на анимацији условљеној емоционалном реакцијом на одређени стимулус. Стимулуси и емоционалне реакције унапред су унете, односно програмиране, тако да се може рећи да постоји одређени алгоритам у складу са којим се карактери понашају. У репрезентативној литератури, алгоритми се одређују као процедуре корак-по-корак формалних инструкција које решавају проблеме и задатке и постижу резултате у ограниченом броју корака (Paul 2008: 247). Опште је познато да било какав рад софтвера и компјутера јесте реализација алгоритама уз помоћ неког програмског језика (Paul 2008: 247).

Истраживањем виртуелне природе ових карактера, као и њихових емоционалних реакција могу се истражити неке специфичности виртуелног експресије лица и виртуелне мимике. Занимљиви су закључци до који се може доћи у вези са невербалном комуникацијом. Једном речју, код ових карактера сви аспекти њиховог „понашања“ условљени су њиховом виртуелном природом. Начин презентације је доследан њиховој „природи“, односно, као што се то и види, ови карактери су настали помоћу компјутера, односно, у компјутеру, а визуелно су приказани на монитору компјутера. Дакле, финална презентација тродимензионалних карактера је на монитору компјутера.

\section{0. Дигитална платформа Емоционатор}

Пре него што детаљније опишем своје тродимензионалне карактере, додао бих радну дефиницију „карактера“у мојој платформи. Каркатер у Емоционатору би био сваки објекат који сам анимирао са извесном изражајношћу, а који својим деловањем може да комуни- 
цира са публиком, односно, реципијентима моје платформе. У Емоционатору тродимензионални карактер је анимиран са изражајношћу условљеном емоционалном реакцијом на одређени дводимензионални стимулус, а постоји комуникација са корисником, односно, постоји повратна спрега између карактера и корисника. Ослањајући се на карактеристике компјутерксе анимације, као и специфичности рада у Flash-y, код мене је тродимензионални карактер одређен кроз анимацију, а акценат је на емоционалним реакцијама (претежно мимика и гест карактера).

Емоционатор је створен у програмима за обраду слике и звука. Као извршни програм покреће се на оперативном систему који подржава покретање одређеног софтверског формата у коме је пројекат забележен. Овако покренута дигитална платформа приказује се пред корисником у прозору. Такође је могуће приказати слику преко целе површине екрана, али пошто није предвиђена за приказивање у таквој резолуцији може доћи до празних површина на којима нема дефинисане слике. Зато је препоручљиво користити је у предвиђеној резолуцији односно прозору у ком се сама активира. Резолуција платформе је одређена на 1024 пута 768 пиксела.

Дигитална платформа подељена је на два дела, односно на почетну и изабрану страну. Почетна страна садржи: 1. управљачки интерфејс, 2. назив платформе и 3. позадину. Због саме чињенице да се при сваком стартовању безусловно ова страна појављује на екрану испред корисника називамо је почетна. Из ове странице се даље одабиром кроз управљачки интерфејс стиже до осталих могућих страна. Постоје четири различите странице које су могуће за одабир. Неке можда и неће бити одабране док поједине могу бити и више експлоатисане, а све у зависности од афинитета корисника, саме емоционалне реакције корисника и његовог односа према слици која се налази испред њега.

За позадину на почетној страни одабрана је црна боја због своје неупадљивости и карактеристике да истакне остале обојене елементе на слици. На страници се као упадљиве истичу две појединости, а то су управљачки интерфејс и назив пројекта који јасно ствара идентитет софтверског остварења и ближе одређује његову функцију. 
Назив платформе је беле боје, а смештен је у горњи средишњи део прозора. У доњем делу се налазе дугмићи за прелазак на жељену страницу, као што је приказано на слици 3.0.1.

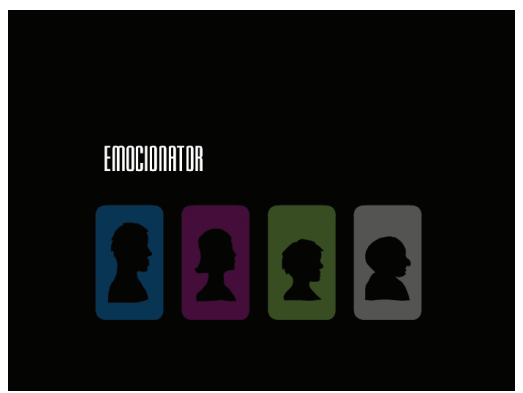

Слика 3.0.1. Почетна страна платформе Емоционатор.

До изабране стране долази се преласком поинтера преко једног од дугмета на почетној страни и његовој активацији. Можемо одабрати једну од четири понуђених страна. Свака страница садржи своје сопствене и заједничке карактеристике. Заједничко за све стране је дизајн стране, који се битно не мења. Промена се састоји у боји позадине стране и карактера који се налази на тој страници. Поред тога, ту је управљачки интерфејс који је идентичан на свакој страни. Затим, ту су и стимулуси представљени у прозору у левом углу. На десној страни екрана се налази тродимензионална глава која представља одређени карактер.

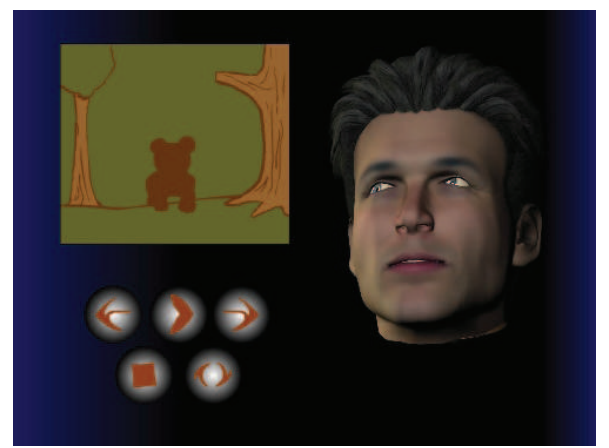

Слика 3.0.2. Дигитална интерактивна анимирана глава која припада виртуелном карактеру. 
Код управљачког интерфејса као и код описа дигиталне платформе, ради лакшег схватања и детаљнијег описа, поделио сам опис на два дела односно почетну страну и изабрану страну. На првој страни налази се одређен број дугмића, односно четири. Дугмићи су по свом спољном облику идентични. Разлика је у боји и приказу цртежа који се налази у средишњем делу дугмета, као и његовој анимацији. Цртеж на средини дугмета је замишљен као силуета која асоцира на карактер, на чију страницу притиском на дугме треба да одемо. Само дугме је анимирано тако што реагује када се поинтером пређе преко њега приказујући још једну мању силуету светлијег интензитета од боје дугмета. Боја дугмета не одређује карактер, али је постављена са намером да својом блажом асоцијацијом код неких примера, општеприхваћених у друштву, направи разлику пола, узраста и категорије изабраног карактера. Следствено томе, за страницу која представља мушкарца као карактер одабрао сам плаву боју. За страницу где је жена одабрана је лила боја, затим зелена за дечака, бледо сива за старца.

Распоред дугмића насумично је постављен без претераног значења или утицаја на избор који корисник треба да учини. Сви дугмићи постављени су у једној линију у низу са истим међурастојањем. Висина и величина дугмета одабрана је за просечног корисника са циљем да јасно види слику при одабиру карактера, а да при том не ремети дизајн стране.

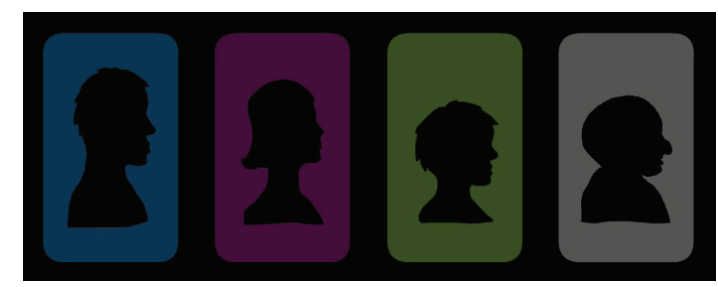

Слика 3.0.3. Илустрација дугмића за одабир виртуелног карактера.

Свака од четири одабране стране, колико их укупно има у избору, садржи идентичан број дугмића и њихову функцију. Управљачки интерфејс на овим страницама садржи пет дугмића идентично постављених у простору. Нису посебно груписана већ представљена 
скоро као целина. Дугмићи су кружног облика са идентично обојеном позадином, постављеном у средину, која из светлије сиве прелази ка тамнијим тоновима, ширећи се кружно до ивице самог дугмета које је црне боје. Разлика између дугмића представља пиктограм постављен у средини и његову анимацију, која је различита у зависности од функције дугмета. Све функције дугмића, осим дугмета за промену карактера, односе се на управљање стимулусом који је представљен као анимација у формату квадрата, а који је постављен у горњем левом углу одмах изнад самих дугмића.

Према својој функцији, дугмиће делимо на пет одређених, постављених у два реда. Крајње лево дугме првог реда, у средини садржи стрелицу која показује на леву стану, као и њену анимацију. У анимацији, стрелица иде у одређену страну и учесника ближе асоцира на значење одабира. Анимација је кружног карактера. Притисак на ово дугме резултира да се стимулус, односно слика из које креће анимација промени на претходно приказану, односно, претходну слику. Испод описа налазе се илустрације како то изгледа у самој платформи.

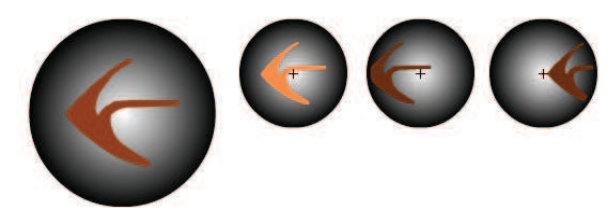

Слика 3.0.4. Илустрације дугмића 1а у платформи Емоционатор.



Слика 3.0.5. Илустрација дугмића 16 у платформи Емоционатор. 
Крајње десно дугме садржи идентични цртеж и анимацију, само супротног смера. Односно, садржи стрелицу која иде на десну страну и за разлику од леве означава наредну слику стимулуса, односно следећу. У централном делу горњег реда постављано је дугме које означава акцију. Слика подсећа на општеприхваћени пиктограм 'play' и управо означава почетак анимације која се приказује и представља стимулус. Као и остала, и ово дугме садржи кратку анимацију, као што је илустровано испод. Лево постављено дугме у другом реду означава престанак акције, односно заустављање анимације која представља стимулус. На њему је нацртан скоро правилан квадрат који алудира на општеприхваћени пиктограм 'stop'. Такође садржи анимацију која се активира преласком поинтера преко дугмета.

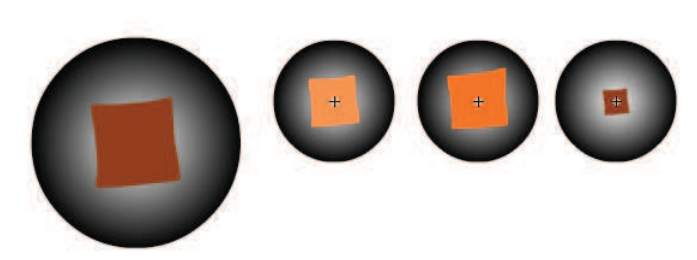

Слика 3.0.6. Дугмићи управљачке платформе 2а.
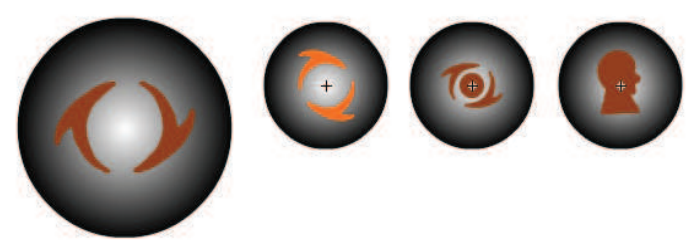

Слика 3.0.7. Дугмићи управљачке платформе 26.

Десно постављено дугме на себи има нацртане две стрелице кружно постављене. Означавањем дугмета покреће се анимација, где се стрелице ротирају у правцу казаљке на часовнику, скупљају и мењају облик, да би на крају анимације начиниле силуету фигуре човека. Ово дугме има функцију да врати корисника на почетну страну одакле би поновним избором могао отићи на страну другог карактера. Ова функција доступна је и активира се у било ком 
жељеном тренутку од стране корисника. Па, с обзиром на функцију ово дугме би могли назвати 'промена'.

У горњој левој половини, на изабраној страници, налази се мањи прозор који садржи кратак приказ анимација, при чему оне дефинишу стимулус који утиче на тродимензионални карактер, који се налази на другој половини стране. Оне су у виду кратке анимиране форме, врло прецизне и јасних значења. Представљене су дводимензионалном техником анимације. Анимације, односно стимулуси у циклусу који се одиграва пред корисником започињу статичном сликом. Она је јасно дефинисана и наговештава амбијент у коме ће се стимулус даље остварити.

\section{0. Анимација 2Д стимулуса и $3 Д$ карактера у Емоционатору}

Анимације које се приказују на платформи у својству стимулуса представљене су прво као базична слика. Она је променљива, и њена промена се врши активацијом одређених дугмића који су постављени ниже испод слике. Користио сам неки елемент или појаву као базичну слику, која би касније преко анимације добила свој карактер и одређивала неки од понуђених стимулуса. Базична слика се појављује на свакој изабраној страници, осим на почетној. Постављена је у горњем левом углу и део је стимулуса који представља, односно представља почетак анимације пре њеног активирања. Свака базична слика се насумично активирањем дугмета 'play' развија у једну од могућих завршетака анимације. Понуђено је неколико различитих и у неким случајевима супротних крајева анимације, односно смисао њихових значења је различит и тако чине различиту врсту стимулуса који касније утиче на тродимензионални карактер.

Врста стимулуса није дефинитивна, већ је заснована на претпоставци како би тродимензионални карактер могао да реагује на исту. Понуђени крајеви анимације су управо зато међусобно различити. Самим тим, карактер тродимензионалног лика игра пресудну улогу у одређивању врсте стимулуса који приписујемо одређеној анимацији. 


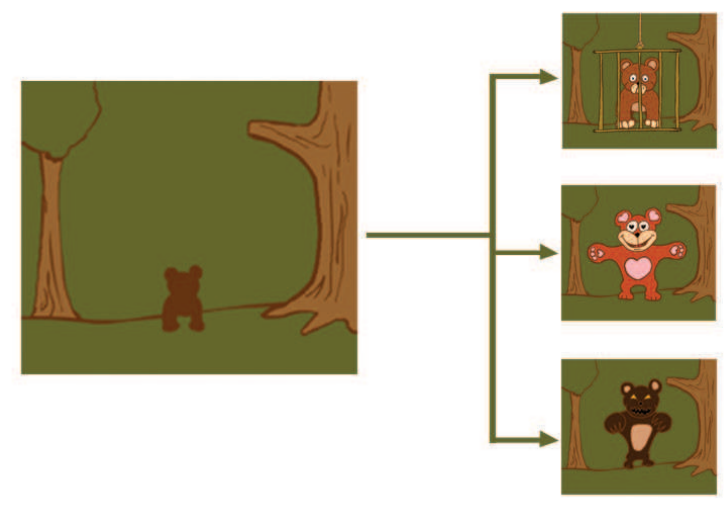

Слика 4.0.1. 2Д анимација карактера и понуђени стимулуси.

Анимације стимулуса представљене су дводимензионалном анимацијом у виду краће форме (слика 4.0.1.). Анимације су рађене у програму 'Flash' у резолуцији 400 пута 350 пиксела. Оне су урађене у виду карикатура, дводимензионално и без сложених детаља. Тиме су намерно одвојене од тродимензионалног карактера, јасно правећи разлику између нечега што би требало бити стимулус и карактера на који тај стимулус утиче.

У цртежу анимације доминира 'outline' испуњен углавном једном бојом. Извесни детаљ се појављује као део сенке или светла и садржи исту, само светлију или тамнију боју. Поједине анимације пропраћене су звуком, али не да би битније нагласиле сцену или ближе одредиле стимулус, већ ради боље импресије при гледању. Анимације започињу статичном сликом, а исто тако се и завршавају, па враћају на почетак. Можемо је поново покренути активацијом на дугме 'play', али не можемо бити сигурни да ли ћемо још један пут видети исту анимацију. Анимација ће започети исто, али програм ће са̂м насумично одредити верзију оне коју ће корисник видети, односно оне која ће утицати својим садржајем на тродимензионални карактер. Промену почетне слике, односно групе анимација која је одређена базичном сликом мењамо управљачким интерфејсом који је одређен за то.

У платформи су релевантне и базичне слике у анимираном стимулусу. Базичне слике су оне статичне слике које представљају 
групу стимулуса, односно представљају основу или базу из које се анимацијом даљим садржајем ближе одређује стимулус. Базична слика може описати, представити простор или појаву која ће се у виду анимације касније дефинисати, али сама по себи нема неки велики значај. Без анимације она би могла представити неки стимулус, али он би могао само утицати на тродимензионални карактер, ако је он детаљно испрофилисан, па рецимо да слика неког предмета изазове одређену реакцију код њега. У мом раду тродимензионалним ликовима може се приписати одређени карактер, али само на основу реакција на стимулусе. Наравно, модификацијом самог програма или детаљнијим профилисањем тродимензионалног карактера могуће је постићи и комплекснији вид реакције. У мом програму је дефинисано да карактер не реагује на базичну слику (слике 4.0.2.-4.0.6.), али и да његова реакција почиње тек након започете анимације.

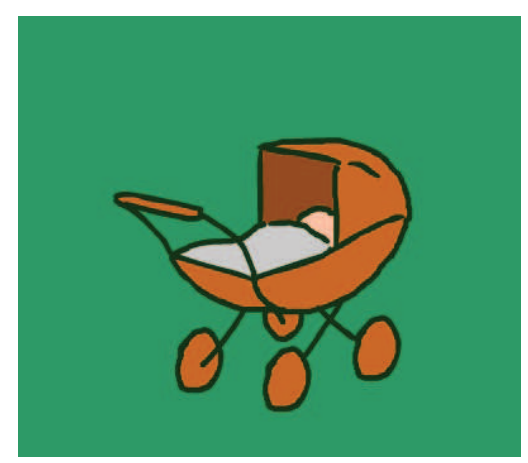

Слика 4.0.2. Базична слика групе „беба“.

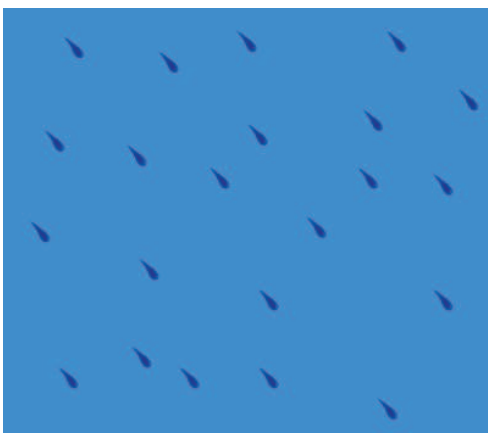

Слика 4.0.3. Базична слика групе „киша“. 


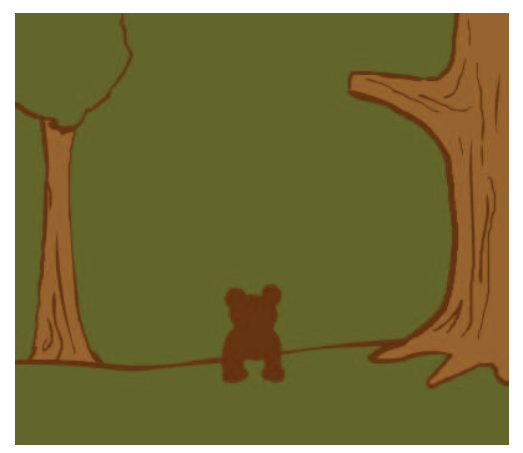

Слика 4.0.4. Базична слика групе „медвед“.

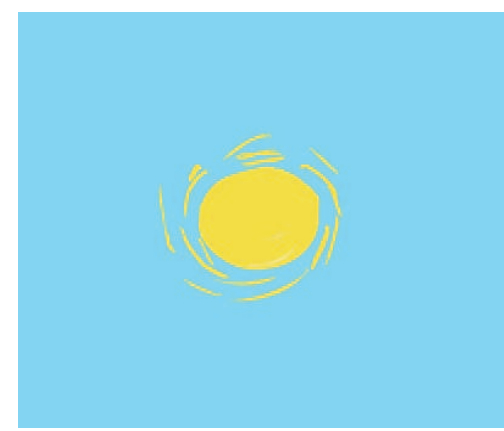

Слика 4.0.5. Базична слика групе „сунце“.

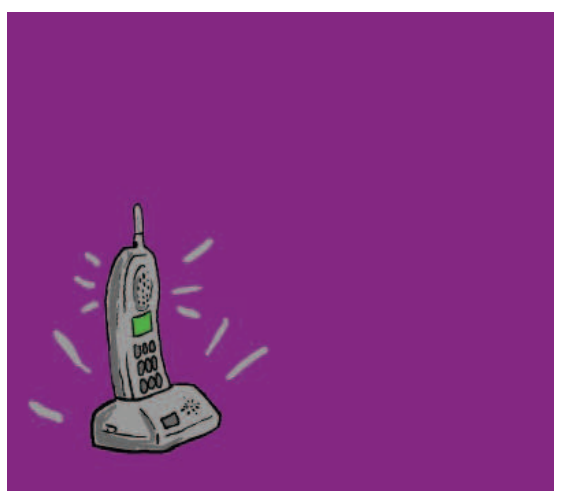

Слика 4.0.6. Базична слика групе „телефонски позив 
На изабраној страни, поред управљачког интерфејса и кратке анимације, која чини стимулус, налази се још и тродимензиона глава. Та глава представља карактер човека, жене, детета и старца. Корисник преко управљачког интерфејса покреће стимулус који утиче на тродимензионални карактер изазивајући одређену реакцију на њему, односно карактер испољава емоције путем експресије. Тродимензионални карактер је заправо измоделована глава која је мапирана и приближно реалистична. Она представља њега или њу, ону на коју се путем интеракције реагује. Интеракцијска веза између корисника и стимулуса, стимулуса и тродимензионалног карактера је повезана, а са односом који се ствара између корисника и тродимензионалног карактера чини једну целину.

Тродимензионална глава представља инструмент којим треба представити одређену емоцију. Да би се одређена емоција приказала, на глави је потребно употребити фацијалне експресије. За сврху мог рада спровео сам кратко истраживање о фацијалним експресијама путем слика које сам правио стављајући себе у улогу глумца (види: фотографије 4.0.1., 4.0.2. и 4.0.3.). Направио сам серију фотографија са експресијама сопственог лица и касније сам их пројектовао на беживотну тродимензионалну главу. Овим путем обухватио сам најчешће и најекстремније експресије као сто су смех, туга, бес итд.

Анимација лица се изводи постављањем екстремних поза емоција, које се потом комбинују. У овом делу рада пажњу ћу посветити видовима на којима се заснива фацијална експресија реалистичних модела, а ту је и анализа функција мишића лица приликом изражавања неких емоција. Од ове полазне тачке, усмерио сам се на детаљну анализу функција мишића лица. Такође, узео сам у обзир и њихово груписање у зоне, и то: зону чела, носа, образа, усана, браде и очију. Нисам узео у обзир све мишиће лица, већ само неке који би могли на прави начин приказати фацијалне експресије емоција. У прилогу се налазе слике која садржи фотографије неких од експресија које сам добио као резултат приликом свог истраживања. 


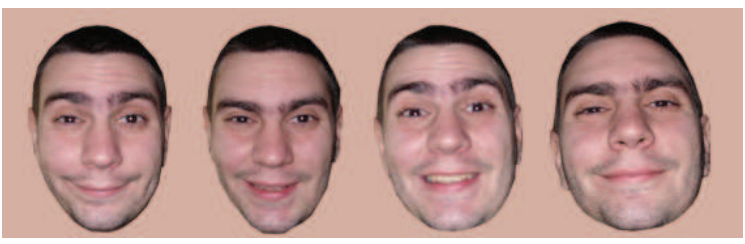

Фотографија 4.0.1. Резултати испитивања експресија лица 1 а.

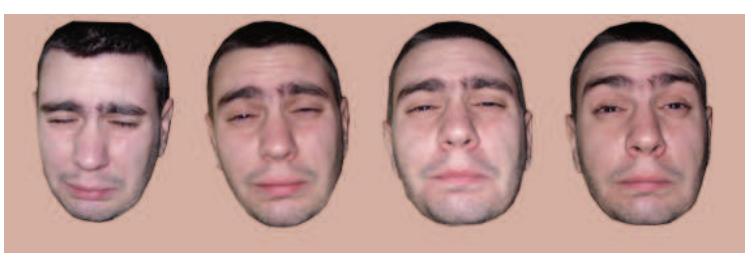

Фотографија 4.0.2. Резултати испитивања експресија лица 16.

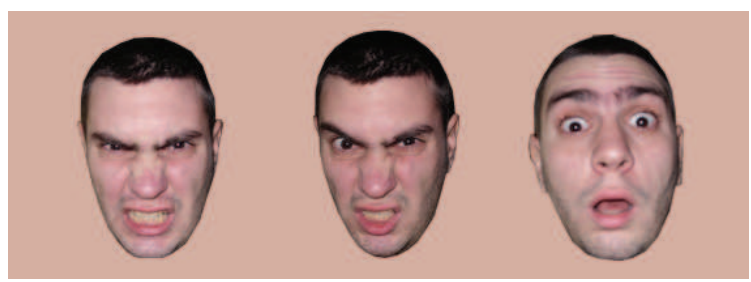

Фотографија 4.0.3. Резултати испитивања експресија лица 1в.

Применио сам резултате истраживања на тродимензионални модел, односно, беживотном моделу сам доделио емоције базиране на реалном моделу (из истраживања). У складу са тим резултатима, моделована је конкретна глава, а овде илуструјем само неке од експресија емоција (слике 4.0.5-4.0.11.). 


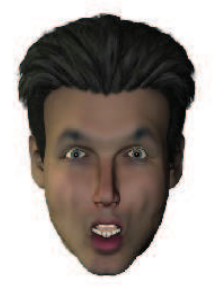

Слика 4.0.5. Експресија „изненађен“.

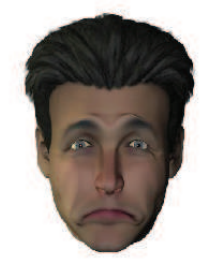

Слика 4.0.6. Експресија лица „тужан“.

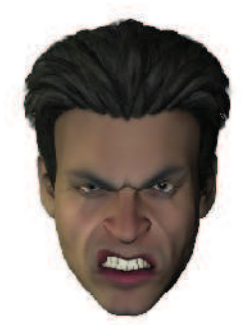

Слика 4.0.7. Експресија лица „бесан“.

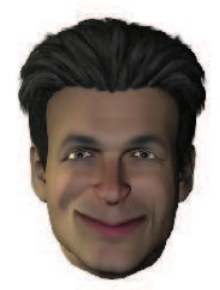

Слика 4.0.8. Експресија лица „радостан“. 


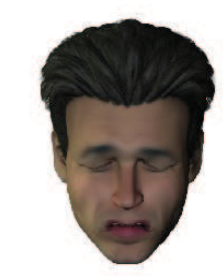

Слика 4.0.9. Експресија лица „разочаран“.

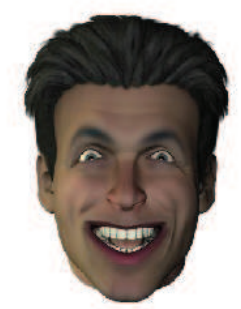

Слика 4.0.10. Експресија смеха.

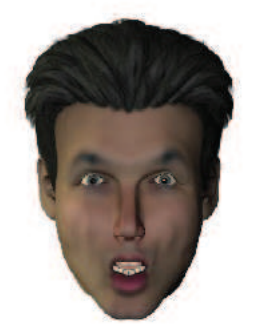

Слика 4.0.11. Експресија лица „уплашен“.

Из наведеног, може се закључити да се дигитална платформа Емоционатор посматра као генератор емоционалних стања. Другим речима, Емоционатор интеракцијом између корисника, дводимензионалног стимулуса и тродимензионалног карактера генерише неку од понуђених емоционалних стања (на пример: бес, срећа, туга, итд.). На тај начин, генерише се и одређена фацијална експресија тродимензионалног карактера, а самим тим, се генерише и неодређена реакција корисника дигиталне платформе Емоционатор. 


\section{0. Закључне напомене}

Након завршетка и реализације платформе Емоционатор, који је био дуготрајан, уочио сам да су се отворила различита питања, поред саме основне идеје о интеракцији емоција између корисника и вештачки направљеног карактера. Дотакнуто је више области дигиталне уметности и компјутерске анимације које нисам могао све да обухватим, али се надам да ћу у даљем уметничком раду истраживати сву ту занимљиву проблематику.

Током рада на платформи, било је изазовно и занимљиво бавити се проучавањем и применом читаве области психологије која се бави емоцијама и емоционалним стањима, као и конкретном применом психологије емоција у домену дигиталне уметности. То није увек могло да буде идеално. Сем тога, ни у реалном животу немамо коначан скуп емоционалних стања. Сматрам да даљим развојем програма и његовом модификацијом могу дати допринос и у оквиру експерименталне психологије.

Такође, током дуготрајног рада на дигиталној интерактивној платформи отворила су се и многа друга питања, на која барем за сада не могу да дам одговор, али би било интересантно да се истраже. Једно од њих је, свакако, и симулација емоција у виртуелном простору (у компјутеру), али и идентитет виртуелних карактера у виртуелном простору. То би могло да буде једна од основних идеја у неком каснијем истраживању.

Мислим да сам успео да интердисциплинарно спојим емоционалну психологију и дигиталну уметност у оној мери у којој ми је то дозвољено с обзиром на садашње стање технологије и садашње стање софтверских алата којима располажемо.

\section{Литература}

Baudrillard, Jean. Simulacija i zbilja. Zagreb: Naklada Jesenski i Turk i Hrvatsko sociološko društvo, 2001. Print.

Baudrillard, Jean. Inteligencija zla ili pakt lucidnosti. Zagreb: Naklada Ljevak, 2006. Print. Bodrijar, Žan. Simulakrumi i simulacija. Novi Sad: IP Svetovi, 1991. Print. 
Haraway, Donna. "A Cyborg Manifesto," The New Media Reader. Ed. Noah Wardrip-Fruin and Nick Montfort. Cambridge, Massachusetts: The MIT Press, 2003. 516. Print.

Krstić, Dragan. Psihološki rečnik. Beograd: Vuk Karadžić, 1988. Print.

Kuspit, Donald. The Matrix of Sensation: VI - Digital Artists and the New Creative Renaissance, 2016.

http://www.artnet.com/magazineus/features/kuspit/kuspit8-5-05.asp[pristupljeno 02.02.2016]

Lane, Richard J. Jean Baudrillard. London and New York: Routledge and Taylor \& Francis Group, 2000. Print.

Maiocchi, Marco. The Neuroscientific Basis of Successful Design: How Emotions and Perceptions Matter. New York: Springer, 2015. Print.

Manovich, Lev. Software Takes Command. New York: Bloomsbury, 2013. Print.

Ognjenović, Predrag i Bojana Škorc. Naše namere i osećanja. Beograd: Gutenbergova galaksija, 2005. Print.

Paul, Christiane. Digital Art. Revised and Expanded Edition. London: Thames \& Hudson Ltd., 2008. Print.

Plutchik, Robert. "Measuring emotions and their derivatives," Emotion: Theory, Research, and Experience - Volume 4: The Measurement of Emotions. Ed. Robert Plutchik and Henry Kellerman. New York: Academic Press, 1989. 1-35. Print.

Šuvaković, Miško. Pojmovnik suvremene umjetnosti. Zagreb i Ghent: Horetzky i Vlees \& Beton, 2005. Print.

TenHouten, Warren D. A General Theory of Emotions and Social Life. London and New York: Routledge and Taylor \& Francis Group, 2007. Print.

Toffoletti, Kim. Baudrillard Reframed. London: I. B. Tauris \& Co. Ltd., 2011. Print.

van der Vyver, Leanie. Playing God. Amsterdam: Gerrit Riteveld \& designLAB, 2012. Print. 


\title{
Milan D. Đurić \\ University Union in Belgrade \\ The Faculty of Computer Science
}

\section{DIGITAL INTERACTIVE ANIMATED GENERATOR OF EMOTIONAL STATES}

\begin{abstract}
Summary
In this paper, I present the digital interactive animated generator of emotional states - Emotionator (Serbian: Emocionator). This project has been carried out in the form of Flash animation, and represents the fusion of expanded media and digital art.

Taking into account human emotions in the context of the psychology of emotions, I set about solving the problem of interface between psychology of machines and a user. Furthermore, I observe digitalisation and designing human emotions whilst focussing on human facial expressions. More specifically, the platform of the project is a digital one, whilst the control interface is entirely the author's own creation. Within this platform, three-dimensional characters respond to combination of diverse previously determined stimuli. The emphasis has been placed on the stimulus in the digital platform, the animation of the given stimulus, as well as the basic picture in the animated stimulus.

In the first part, the paper surveys general data on digital art. The second part provides the theoretical background describing traditional and modern findings about emotions and emotional states and the subsequent application within my own research. Nevertheless, it relies also on representation and simulation of reality connected with designing emotions. It inevitably focuses on psychology of the machine, the computer and a user, and connects these findings with my own digital platform - Emotionator, whilst the third part deals with character animation and the plausible virtual space in Emotionator. The next part focuses on stimuli and animation of 3D and 2D characters, and the final part summarises my findings. In the course of the project, I utilised the digital tools in the form of Flash application, and methods and principles aimed at generating images and animations prepared by means of the computer utilising mostly standard programs for pictures and animations. Finally, in the concluding remarks, certain possible directions of further research in the field of digital art in connection with emotional states have been provided in addition to further possibilities of designing and digitalisation of human emotions.
\end{abstract}

Key Words: Digitalisation, Digital Art, Flash, Emotions, Designing Emotions, Psychology of Emotions, Emotionator. 